\title{
Pengaruh Jarak Tanam terhadap Pertumbuhan dan Produksi Jagung (Zea Mays L) Non Hibrida di Lahan Balai Agro Teknologi Terpadu (ATP)
}

\author{
Trimin Kartika \\ e-mail: triminkartika1969@gmail.com \\ ${ }^{1}$ Program Studi Biologi Fakultas MIPA, Universitas PGRI Palembang
}

\begin{abstract}
The research entitled: The Effect of Planting Distance on Growth and Production of Non Hybrid Maize (Zea Mays L) in the Land of Integrated Technology Agro Center (ATP) ". Aim to get the optimal spacing (maximum production) in non-hybrid corn. The study was conducted in February 2018 until July 2018, located at the Integrated Agro Technology Land (ATP), Bakung Village, Inderalaya District, Ogan Ilir District (OI), South Sumatra Province, South Sumatra Province. The design used was Completely Randomized Design with 27 treatment combinations which were repeated as many as 3 replications. The results showed that the use of rare spacing could increase the growth and production of corn plants, at spacing of $80 \mathrm{~cm} \times 20 \mathrm{~cm}$, and spacing of $100 \mathrm{~cm} \times 50$ $\mathrm{cm} \times 20 \mathrm{~cm}$, giving the best influence on the growth and production of corn plants, non hybrid Srikandi corn with the use of a spacing of $75 \mathrm{~cm} \times 15 \mathrm{~cm}$ giving the highest yield of 4.9 tons / ha.
\end{abstract}

Keywords: Effect of spacing, growth, production, non-hybrid corn

\begin{abstract}
ABSTRAK
Penelitian yang berjudul : Pengaruh Jarak Tanam Terhadap Pertumbuhan Dan Produksi Jagung (Zea Mays L) Non Hibrida Di Lahan Balai Agro Teknologi Terpadu (Atp)”. Bertujuan untuk mendapatkan jarak tanam yang optimal (Produksi yang maksimal) pada jagung non hibrida. Penelitian dilaksanakan pada Februari 2018 sampai Juli 2018, bertempat di Lahan Agro Teknologi Terpadu (ATP), Desa Bakung, Kecamatan Inderalaya, Kabupaten Ogan Ilir (OI) Provinsi Sumatera Selatan Provinsi Sumatera Selatan. Rancangan yang digunakan Rancangan Acak Lengkap dengan 27 kombinasi perlakuan yang diulang sebanyak 3 ulangan. Hasil penelitian menunjukkan bahwa Pemakaian jarak tanam yang jarang dapat meningkatkan pertumbuhan dan produksi tanaman jagung, pada jarak tanam $80 \mathrm{~cm}$ x $20 \mathrm{~cm}$, dan jarak tanam $100 \mathrm{~cm} \times 50 \mathrm{~cm} \times$ $20 \mathrm{~cm}$, memberikan pengaruh terbaik terhadap pertumbuhan dan produksi tanaman jagung, jagung non hibrida Srikandi dengan pemakaian jarak tanam $75 \mathrm{~cm}$ x $15 \mathrm{~cm}$ memberikan hasil tertinggi sebesar 4,9 ton/ha
\end{abstract}

Kata Kunci: Pengaruh jarak tanam, Pertumbuhan, Produksi, Jagung Non Hibrida

\section{PENDAHULUAN}

Di Indonesia rata-rata produktivitas tanaman jagung masih sangat rendah, baik untuk tingkat Nasional, maupun tingkat daerah Sumatera Selatan yaitu sekitar 2.7 ton/ha (Riset dan Teknologi: Seksi
Pembenihan Harian Bimas, Sum-Sel,2003). Produktivitas jagung di Sumatera Selatan relatif masih rendah yakni 3,81 ton/ha, masih jauh di bawah produktivitas nasional yakni 4,57 ton/ha (Badan Pusat Statistik.,2012). 
Rendahnya produktivitas jagung ini disebabkan oleh teknik budidaya yang tidak intensif. Sebagian besar petani masih menggunakan varietas lokal, adanya serangan hama lalat bibit (Atherigona sp) dan penyakit bulai (Peronoscterospora maydis), maupun pemakaian pupuk yang tidak optimal. Hasil penelitian yang telah dilakukan untuk budaya jagung dapat mencapai tingkat produktivitas 10,0 ton/ha (Subandi et al.,2006).

Hasil studi di Agro Teknologi Terpadu (ATP) menggunakan varietas hibrida C-7 dengan jarak tanam $60 \mathrm{~cm}$ x 20 $\mathrm{cm}$, dan pemupukan yang optimal mampu menghasilkan 4.5 ton/ha pipilan kering semestara potensi hasil adalah $10-12$ ton/ha pipilan kering. Disamping pemupukan faktor lain pertumbuhan dan hasil jagung misalnya populasi tanaman yang dipengaruhi oleh jarak tanam dan jumlah tanaman per lubang. Penggunaan jarak tanam yang tepat akan memberikan hasil yang tinggi. Penambahan populasi tanaman akan meningkatkan hasil, tetapi bila populasi terus ditingkatkan hasil jagung justru menurun, dengan demikian diperlukan suatu populasi yang optimum dari jarak tanam yang tepat untuk mencapai hasil yang maksimum (Djauhari et al,1987).

Salah satu usaha untuk meningkatkan produktivitas tanaman yaitu dengan mengatur jarak tanam atau kepadatan tanaman per satuan luas (Suprapto, 1992). Populasi tanaman (jarak tanam) merupakan salah satu faktor yang dapat mempengaruhi hasil tanaman. Penanaman dengan jarak tanam bertujuan agar populasi tanaman mendapatkan bagian yang sama terhadap unsur hara yang diperlukan dan sinar matahari, dan memudahkan dalam pemeliharaan (Probowati 2014).

Menurut Haryadi (1988), kerapatan tanaman mempengaruhi penampilan dan produksi tanaman. Pada umumnya produksi per satuan luas yang tinggi di dapat dari populasi tertentu yang dapat memanfaatkan penggunaan cahaya secara maksimal. Menurut Gardner et al. (1996), pengaturan kerapatan tanaman bertujuan untuk meminimalkan kompetisi intrapopulasi agar kanopi dan akar tanaman dapat memanfaatkan lingkungan secara optimal. jarak tanam jarang (populasi rendah) dapat memperbaiki pertumbuhan individu tanaman, tetapi memberikan peluang terhadap perkembangan gulma. Tanaman jagung bila banyak ditumbuhi gulma berdampak negatif terhadap pertumbuhan dan produksi tanaman jagung karena terjadi kompetisi dalam pemanfaatan unsur hara, air, cahaya dan ruang tumbuh. Jarak tanam yang terlalu lebar dapat mengurangi jumlah populasi tanaman menyebabkan berkurangnya pemanfaatan cahaya matahari, dan unsur hara oleh tanaman, karena sebagian cahaya akan jatuh ke permukaan tanah dan unsur hara akan hilang karena penguapan dan pencucian.

Salah satu usaha dalam meningkatkan produksi jagung adalah dengan pengaturan jumlah tanaman per hektar atau jarak tanam yang merupakan faktor penting untuk mendapatkan hasil yang tinggi. Seperti halnya pengolahan tanah, hasil jagung dipengaruhi pula oleh jumlah tanaman per satuan luas. Penggunaan jarak tanam yang tepat untuk jenis tanaman ditujukan untuk menghindari persaingan antara tanaman dalam penyerapan air, unsur hara, penggunaan cahaya matahari dan persaingan dengan tumbuhan pengganggu. Penggunaan jarak tanam yang tepat sangat penting dalam pemanfaatan sinar matahari secara maksimum untuk proses fotosintesis (Gerry Dian, 2004).

Dari uraian diatas, maka perlu dilakukan penelitian terhadap "Pengaruh Jarak Tanam terhadap Pertumbuhan dan Produksi Jagung (Zea mays L) non hibrida".

\section{BAHAN DAN METODE}

Penelitian ini dilaksanakan bulan Februari 2018 sampai Juli 2018, bertempat di Lahan Agro Teknologi Terpadu (ATP), Desa Bakung, Kecamatan Inderalaya, Kabupaten Ogan Ilir (OI) Provinsi Sumatera Selatan Provinsi Sumatera Selatan.

Alat yang digunakan dalam penelitian ini antara lain: cangkul, parang, 
ember, meteran, timbangan, oven, tali plastik, papan merek, alat tulis, pemeliharaan tanaman, dan alat analisis kimia. Sedangkan bahan yang digunakan dalam penelitian ini adalah: benih jagung non hibrid srikandi, pupuk kotoran ayam, pupuk urea : $300 \mathrm{~kg}$, SP-36: $100 \mathrm{~kg}$, KCL; $50 \mathrm{~kg}$, kapur 1,5 ton/ha, insektisida yang mengandung bahan aktif karbofuran, Deltrametrin dan furadan, herbisida Noxone yang mengandung bahan aktif Paraquat, air dan bahan-bahan lain yang diperlukan.

Metode yang digunakan dalam penelitian ini adalah metode menggunakan Rancangan Acak Lengkap dengan 27 kombinasi perlakuan yang diulang sebanyak 3 ulangan. Perlakuan yang diteliti varietas jagung non hibrida yaitu Srikandi, sedangkan perlakuan jarak tanaman adalah :

$\mathrm{P} 1$ = Jarak tanam $80 \mathrm{~cm} \times 20 \mathrm{~cm}$ (1 biji/lubang), P2 = Jarak tanam $100 \times 50 \times 20$ $\mathrm{cm}$ (1 biji/lubang), P3 = Jarak tanam $75 \mathrm{~cm} \mathrm{x}$ $20 \mathrm{~cm}$ (1 biji/lubang), P4 = Jarak tanam 75 $\mathrm{cm}$ x $40 \mathrm{~cm}$ (2 biji/lubang), P5 = Jarak tanam $70 \mathrm{~cm} \times 20 \mathrm{~cm}$ (1 biji/lubang), P6 = Jarak tanam $65 \mathrm{~cm} \times 20 \mathrm{~cm}$ (1 biji/lubang), P7 = Jarak tanam $75 \mathrm{~cm} \times 50 \mathrm{~cm}$ (3 biji/lubang), P8 = Jarak tanam $60 \mathrm{~cm} \times 20 \mathrm{~cm} \mathrm{(1}$ biji/lubang) , P9 = Jarak tanam $75 \mathrm{~cm} \mathrm{x} 15$ cm (1 biji/lubang)

\section{PELAKSANAAN PENELITIAN Persiapan Lahan}

Lahan yang digunakan seluas 0,3 ha. Lahan dibersihkan dan semua vegetasi yang ada lalu diolah dengan menggunakan traktor dibajak dua kali dan digaru untuk meratakan tanah. Selanjutnya dibuat petakan sejumlah lima puluh empat petak, setiap petak berukuran $8 \mathrm{~m}$ x $6 \mathrm{~m}$. Jarak antar petakan 1 meter dan jarak antar ulangan 2 meter. Setelah itu dibuat larikan dan jalur tanam. Dilakukan pengapuran dengan jumlah kapur yang diberikan 1,5 ton per hektar diberikan dengan cara secara sebar merata bersamaan dengan pengolahan tanah.Pengapuran dilakukan satu minggu sebelum tanam.

\section{Pemupukan}

Pemupukan dilakukan saat pengolahan tanah terakhir. Pupuk kandang kotor ayam diberikan dalam larikan di sebelah kanan jalur tanam dengan jarak $7 \mathrm{~cm}$ yang diberikan $3-7$ hari sebelum tanam. Pupuk Urea dosis $300 \mathrm{~kg} / \mathrm{ha}$ diberikan dua kali yaitu $1 / 3$ dosis diberikan saat tanam dan sisanya diberikan saat umur jagung $25-30$ hst, pupuk SP-36 dosis $100 \mathrm{~kg} / \mathrm{ha}$ dan KCL dosis $50 \mathrm{~kg} / \mathrm{ha}$ diberikan seluruhnya saat tanam. Semua pupuk dicampur dengan dilarikan.

\section{Penanaman}

Sebelum ditanam benih jagung direndam selama 1 jam dalam larutan insektisida (Furadan) $10 \mathrm{ml} / \mathrm{kg}$. Setelah direndam dengan insektisida yang mengandung bahan aktif Furadan, benih ditanam dengan cara tugal dengan jarak tanam yang berbeda, dan jumlah biji perlubang sesuai dengan perlakuan. Penanaman dilakukan dengan kedalaman kurang lebih $5 \mathrm{~cm}$.

\section{Pemeliharaan}

Pemeliharaan tanaman meliputi : penyulaman, pembumbunan, penyiangan dan pengendalian hama. Penyulaman dilakukan pada saat tanaman berumur 7 hari setelah tanam. Pembumbunan dilakukan pada saat tanaman berumur 30 hst, penyiangan dilakukan dua kali pada saat tanaman berumur 30 dan 60 hst. Pengendalian hama dilakukan bila ada gejala serangan hama atau penyakit, segera dilakukan penyemprotan dengan insektisida dan herbisida Noxone yang mengandung bahan aktif Paraquat.

\section{Pemanenan}

Pemanenan dilakukan dengan cara memotong bagian atas tanaman 5 sampai 10 $\mathrm{cm}$ dari tongkol, dengan tujuan untuk mempercepat pengeringan jagung. Panen dilakukan pada saat tanaman matang fisiologis dengan ciri klobot telah berwarna kuning, biji jagung telah mengeras, mengkilat dan bila ditekan dengan kuku tidak meninggalkan bekas. 


\section{Parameter Pengamatan Tinggi tanaman}

Tinggi tanaman $(\mathrm{cm})$ diukur dari permukaan tanah sampai keujung daun yang terpanjang. Pengukuran dilakukan saat tanaman berumur $14,28,42,56$ hst.

\section{Waktu keluar bunga}

Waktu keluar bunga jantan/betina (hst), ditentukan dengan melihat waktu tanaman mengeluarkan bunga jantan/betina sebanyak $50 \%$ dari tanaman sampel, dihitung sebagai waktu keluar bunga.

\section{Kandungan klorofil daun}

Diukur menggunakan klorofil meter (SPAD). Pengukuran dilakukan pada saat tanaman berumur 14, 28, 42, 56 hst. (Awal pembungaan) yang dilakukan pada daun muda yang telah mengembang dengan sempurna pada ujung, tengah dan pangkal daun, kemudian hasil dirata-ratakan.

\section{Indeks Luas Daun ( $\left.\mathrm{cm}^{2}\right)$}

Indeks Luas Daun $\left(\mathrm{cm}^{2}\right)$ (ILD dan ILD rata-rata 14 harian), dihitung dengan menggunakan rumus :

$$
\text { ILD : } \frac{\mathrm{LA}}{\mathrm{P}}
$$

\section{Berat berangkasaaan (g)}

Diukur setelah bagian atas tanaman (batang, daun) dikeringkan dalam oven pada suhu $70^{\circ}$ selama 48 jam setiap sampel.
Pengukuran dilakukan pada saat tanaman berukur 14, 28, 42, dan 56 hst.

\section{Hasil dan komponen hasil}

Setiap komponen hasil dilakukan setelah akhir penelitian (panjang tongkol, diameter tongkol, jumlah baris/tongkol, jumlah biji/tongkol, berat kering klobot, berat kering janggel, berat 1000 butir, produksi dan iklim mikro).

\section{Analisis Data}

Data hasil pengamatan diolah dengan program komputer Statistical Analisis System (SAS 183), dan dianalisis menggunakan analisis keragaman, jika $F$ hitung lebih besar dari $\mathrm{F}$ tabel pada taraf $(0,05)$, (0,)1) maka dilanjutkan Uji BNT (Beda Nyata Trkecil) pada taraf 0,05\% .

\section{HASIL DAN PEMBAHASAN}

Untuk mengetahui pengaruh jarak tanam terhadap pertumbuhan dan hasil jagung hibrid Srikandi, dilakukan analisis sidik ragam yang hasilnya disajikan pada tabel 1. Hasil analisis keragaman menerangkan bahwa perlakuan jarak tanam mengakibatkan perbedaan yang sangat nyata pada semua peubah yang diamati, kecuali peubah yang diamati kandungan klorofil berpengaruh tidak nyata.

Tabel 1. Hasil analisis keragaman pengaruh perlakuan terhadap peubah yang diamati.

Peubah yang diamati

\begin{tabular}{lccc} 
& & $\mathbf{0 , 0 5}$ & $\mathbf{0 , 0 1}$ \\
\hline Tinggi tanaman (cm) & $8,57^{* *}$ & 2,51 & 3,71 \\
Waktu Keluar bunga (hst) & $11,98^{* *}$ & & \\
Kandungan klorofil & $1,14^{\text {tn }}$ & & \\
Indeks Luas Daun (cm ${ }^{2}$ ) & $7,21^{* *}$ & & \\
Berat berangkasan kering (g) & $6,49^{* *}$ & & \\
Panjang tongkol (cm) & $3,85^{* *}$ & \\
Dianmeter tongkol (cm) & $4,16^{* *}$ & \\
Jumlah baris tongkol & $11,32^{* *}$ & \\
Jumlah biji/tongkol (buah) & $9,91^{* *}$ & \\
Berat kering klobot (g) & $5,21^{* *}$ & \\
Berat kering jenggel (g) & $4,109^{* *}$ & & \\
Berat 1000 biji (g) & $6,38^{* *}$ & & \\
Produksi (ton/ha) & $5,12^{* *}$ & \\
\hline
\end{tabular}




\section{Pertumbuhan Tanaman Tinggi Tanaman}

Hasil analisis keragaman menunjukkan perlakuan jarak tanam memberikan pengaruh sangat nyata terhadap tinggi tanaman jagung non hibrida Srikandi. Pengaruh jarak tanam memberikan hasil yang tidak berbeda nyata terhadap tinggi tanaman umur 42 hst, tetapi memberikan pengaruh berbeda nyata terhadap tinggi tanaman jagung umur 14, 28, dan 56 hst yaitu pada jarak tanam P8 $(60 \mathrm{~cm}$ x $20 \mathrm{~cm})$, P9 $(75 \mathrm{~cm} \times 15 \mathrm{~cm})$.

Uji Beda Nyata (BNT) pengaruh perlakuan jarak tanam terhadap tinggi tanaman disajikan pada tabel 2.

Tabel 2. Pengaruh Jarak Tanam Terhadap Tinggi Tanaman Umur 14, 28, 42, dan 56 hst.

\begin{tabular}{|c|c|c|c|c|}
\hline \multirow{2}{*}{$\begin{array}{c}\text { Perlakuan } \\
\text { Jarak Tanam }\end{array}$} & \multicolumn{4}{|c|}{ Tinggi Tanaman $(\mathrm{cm})$} \\
\hline & $14 \mathrm{hst}$ & $28 \mathrm{hst}$ & $42 \mathrm{hst}$ & $56 \mathrm{hst}$ \\
\hline $\mathrm{P} 1=80 \mathrm{~cm} \times 20 \mathrm{~cm}(1 \mathrm{biji} / \mathrm{lubang})$ & $26 \mathrm{a}$ & $117 \mathrm{a}$ & $178 \mathrm{a}$ & $228 \mathrm{a}$ \\
\hline $\mathrm{P} 2=100 \mathrm{~cm} \times 50 \mathrm{~cm} \times 20 \mathrm{~cm}(1 \mathrm{biji} / \mathrm{lubang})$ & $27 \mathrm{a}$ & $115 \mathrm{a}$ & $177 \mathrm{a}$ & $230 \mathrm{a}$ \\
\hline $\mathrm{P} 3=75 \mathrm{~cm} \times 20 \mathrm{~cm}(1 \mathrm{biji} / \mathrm{lubang})$ & $26 \mathrm{a}$ & $119 \mathrm{a}$ & 179 a & $223 a b$ \\
\hline P4 = $75 \mathrm{~cm} \mathrm{x} 40 \mathrm{~cm}$ (2 biji/lubang) & $24 \mathrm{a}$ & $116 \mathrm{a}$ & $172 \mathrm{ab}$ & $220 \mathrm{~b}$ \\
\hline P5 = $70 \mathrm{~cm} \times 20 \mathrm{~cm}$ (1 biji/lubang) & $26 \mathrm{a}$ & $115 \mathrm{a}$ & $171 \mathrm{ab}$ & $218 b$ \\
\hline $\mathrm{P} 6=65 \mathrm{~cm} \times 20 \mathrm{~cm}(1 \mathrm{biji} / \mathrm{lubang})$ & $25 \mathrm{a}$ & $114 \mathrm{a}$ & $172 \mathrm{ab}$ & $213 \mathrm{~b}$ \\
\hline $\mathrm{P} 7=75 \mathrm{~cm} \times 50 \mathrm{~cm}$ (3 biji/lubang) & $21 \mathrm{ab}$ & $113 \mathrm{a}$ & $179 \mathrm{a}$ & $218 b$ \\
\hline P8 $=60 \mathrm{~cm}$ x $20 \mathrm{~cm}$ (1 biji/lubang $)$ & $23 \mathrm{ab}$ & $98 \mathrm{~b}$ & $170 \mathrm{~b}$ & $187 \mathrm{c}$ \\
\hline $\mathrm{P} 9=75 \mathrm{~cm} \times 15 \mathrm{~cm}(1 \mathrm{biji} / \mathrm{lubang})$ & $19 \mathrm{~b}$ & $109 \mathrm{~b}$ & $175 \mathrm{ab}$ & $193 \mathrm{c}$ \\
\hline
\end{tabular}

Tinggi tanaman jagung non hibrida pada umur 14, 28, 42, dan 56 hst bervariasi. Perlakuan jarak tanam P2 $(100 \mathrm{~cm}$ x $50 \mathrm{~cm}$ x $20 \mathrm{~cm}$ ) pada umur tanaman jagung $14 \mathrm{hst}$ dengan nilai tertinggi $27 \mathrm{~cm}$ memberikan hasil yang lebih baik, sedangankan pada perlakuan jarak tanam P9 $(75 \mathrm{xm} \times 15 \mathrm{~cm})$ memberikan nilai hasil terendah yaitu 19 $\mathrm{cm}$. Umur 28 hst perlakuan jarak tanam P1 $(80 \mathrm{~cm} \times 20 \mathrm{~cm}$ ) dengan nilai tertinggi yaitu $117 \mathrm{~cm}$, sedangkan nilai terendah pada perlakuan P8 $(60 \mathrm{~cm} \times 20 \mathrm{~cm})$. Perlakuan jarak tanam P3 ( $75 \mathrm{~cm}$ x $20 \mathrm{~cm}$ ) memberikan nilai tertinggi yaitu $179 \mathrm{~cm}$ pada perlakuan umur 42 hst, sedangkan nilai rata terendah pada perlakuan jarak tanam P8 $(60 \mathrm{~cm} \times 20 \mathrm{~cm})$ yaitu $170 \mathrm{~cm}$. Umur 56 hst nilai tertinggi pada perlakuan
P2 $(100 \mathrm{~cm} \times 50 \mathrm{~cm} \times 20 \mathrm{~cm})$ yaitu $230 \mathrm{~cm}$, sedangkan terendah pada perlakuan P8 (60 $\mathrm{cm}$ x $20 \mathrm{~cm}$ ). Hal ini disebabkan semakin semakin rapat jarak tanam maka akan mempengaruhi rendahnya tinggi tanaman jagung, sebaliknya semakin jarang jarak tanam maka semakin baik pertumbuhan tanaman jagung.

\section{Indeks Luas Daun}

Hasil analisis keragaman menunjukkan perlakuan jarak tanam pengaruh sangat nyata terhadap indeks luas daun jagung non hibrida.

Uji Beda Nyata (BNT) pengaruh perlakuan jarak tanam terhadap indeks luas daun disajikan pada tabel 3 .

Tabel 3. Pengaruh Jarak Tanam Terhadap Indeks Luas Daun Umur 14, 28, 42, dan 56 hst.

\begin{tabular}{lllll}
\hline Perlakuan Jarak Tanam & \multicolumn{4}{c}{ Tinggi Tanaman $(\mathrm{cm})$} \\
\cline { 2 - 4 } & $14 \mathrm{hst}$ & $28 \mathrm{hst}$ & $42 \mathrm{hst}$ & $56 \mathrm{hst}$ \\
\hline
\end{tabular}




\begin{tabular}{|c|c|c|c|c|}
\hline $\mathrm{P} 1=80 \mathrm{~cm} \times 20 \mathrm{~cm}(1 \mathrm{biji} / \mathrm{lubang})$ & $0,8 \mathrm{a}$ & $2,0 \mathrm{a}$ & $3,2 \mathrm{a}$ & $4,1 \mathrm{a}$ \\
\hline $\mathrm{P} 2=100 \mathrm{~cm} \times 50 \mathrm{~cm} \times 20 \mathrm{~cm}$ (1 biji/lubang) & $0,76 \mathrm{a}$ & $2,7 \mathrm{a}$ & $3,6 \mathrm{a}$ & $4,2 \mathrm{a}$ \\
\hline $\mathrm{P} 3=75 \mathrm{~cm} \times 20 \mathrm{~cm}$ (1 biji/lubang) & $0,68 \mathrm{a}$ & $1,9 \mathrm{~b}$ & $3,4 \mathrm{a}$ & $4,1 \mathrm{a}$ \\
\hline $\mathrm{P} 4=75 \mathrm{~cm} \times 40 \mathrm{~cm}$ (2 biji/lubang) & $0,72 \mathrm{a}$ & $1,6 \mathrm{~b}$ & $3,3 \mathrm{a}$ & $3,8 \mathrm{ab}$ \\
\hline P5 = $70 \mathrm{~cm} \times 20 \mathrm{~cm}$ (1 biji/lubang) & $0,7 \mathrm{a}$ & $1,58 \mathrm{bc}$ & $3,2 \mathrm{a}$ & $3,5 \mathrm{bc}$ \\
\hline P6 = $65 \mathrm{~cm} \times 20 \mathrm{~cm}$ (1 biji/lubang $)$ & $0,66 \mathrm{a}$ & $1,5 \mathrm{bc}$ & $3,1 \mathrm{a}$ & $3,4 \mathrm{bc}$ \\
\hline $\mathrm{P} 7=75 \mathrm{~cm} \times 50 \mathrm{~cm}$ (3 biji/lubang) & $0,62 \mathrm{a}$ & $1,3 \mathrm{c}$ & $3,09 \mathrm{a}$ & $3,2 \mathrm{bc}$ \\
\hline P8 = $60 \mathrm{~cm} \times 20 \mathrm{~cm}$ (1 biji/lubang) & $0,4 \mathrm{a}$ & $1,2 \mathrm{c}$ & $2,1 \mathrm{~b}$ & $2,9 \mathrm{c}$ \\
\hline $\mathrm{P} 9=75 \mathrm{~cm} \times 15 \mathrm{~cm}$ ( 1 biji/lubang $)$ & $0,32 \mathrm{a}$ & $1,3 \mathrm{c}$ & $2,5 \mathrm{~b}$ & $2,9 \mathrm{c}$ \\
\hline
\end{tabular}

Hasil indeks luas daun pada tabel 3 menunjukkan perlakuan jarak tanam jagung non hibrida srikandi relatif sama belum berpengaruh terhadap luas daun pada umur 14 hst, tetapi setelah umur 28 hst sudah ada pengaruh nilai tertinggi dicapai pada perlakuan P2 $(100 \mathrm{~cm}$ x $50 \mathrm{~cm}$ x $20 \mathrm{~cm})$ sebesar 2,7 $\mathrm{cm}^{2}$. Pada umur $42 \mathrm{hst}$ perlakuan $\mathrm{P} 2$ menunjukkan luas tertinggi sebesar $3,6 \mathrm{~cm}^{2}$, umur 56 hst nilai tertinggi pada perlakuan P2 sebesar $4,2 \mathrm{~cm}^{2}$. Berdasarkan hasil analisis keragaman menunjukkan perlakuan berpengaruh nyata terhadap indeks luas daun, hal dapat dilihat jika semakin rapat jarak tanam maka indeks luas daun semakin menurun.

Tabel 4. Pengaruh perlakuan jarak tanam terhadap pertumbuhan tanaman jagung yang diamati

\begin{tabular}{|c|c|c|c|}
\hline Perlakuan Jarak Tanam & $\begin{array}{l}\text { Waktu } \\
\text { Keluar } \\
\text { Bunga }\end{array}$ & $\begin{array}{c}\text { Kandungan } \\
\text { Klorofil }\end{array}$ & $\begin{array}{c}\text { Berat } \\
\text { Berangkasan } \\
\text { Kering }\end{array}$ \\
\hline $\mathrm{P} 1=80 \mathrm{~cm} \times 20 \mathrm{~cm}(1 \mathrm{biji} / \mathrm{lubang})$ & $49,0 \mathrm{~b}$ & 52,2 & $163,5 \mathrm{a}$ \\
\hline $\mathrm{P} 2=100 \mathrm{~cm} \times 50 \mathrm{~cm} \times 20 \mathrm{~cm}(1 \mathrm{biji} /$ lubang $)$ & $48,9 \mathrm{~b}$ & 49,8 & $123,5 \mathrm{a}$ \\
\hline P3 = $75 \mathrm{~cm}$ x $20 \mathrm{~cm}$ (1 biji/lubang) & $49,9 \mathrm{~b}$ & 52,6 & $137,0 \mathrm{~b}$ \\
\hline P4 = $75 \mathrm{~cm} \mathrm{x} 40 \mathrm{~cm}$ (2 biji/lubang) & $50,2 \mathrm{ab}$ & 48,2 & $115,5 \mathrm{~b}$ \\
\hline P5 = $70 \mathrm{~cm} \times 20 \mathrm{~cm}$ (1 biji/lubang) & $50,4 \mathrm{ab}$ & 51,5 & $146,3 \mathrm{bc}$ \\
\hline $\mathrm{P} 6=65 \mathrm{~cm} \times 20 \mathrm{~cm}$ (1 biji/lubang) & $50,5 \mathrm{ab}$ & 48,6 & $127,2 \mathrm{bc}$ \\
\hline $\mathrm{P} 7=75 \mathrm{~cm} \times 50 \mathrm{~cm}$ (3 biji/lubang) & $50,3 \mathrm{ab}$ & 48,7 & $132,6 \mathrm{~b}$ \\
\hline P8 = $60 \mathrm{~cm} \times 20 \mathrm{~cm}$ (1 biji/lubang) & $50,5 \mathrm{a}$ & 47,9 & $114,2 \mathrm{bc}$ \\
\hline $\mathrm{P} 9=75 \mathrm{~cm} \times 15 \mathrm{~cm}$ (1 biji/lubang $)$ & $50,6 \mathrm{a}$ & 44,6 & $83,0 \mathrm{c}$ \\
\hline
\end{tabular}

Waktu keluar bunga jantan/betina tanaman jagung non hibrida dipengaruhi oleh perbedaan jarak tanam. Hasil sidik ragam menunjukkan perlakuan jarak tanam memperlihatkan perbedaan yang sangat nyata terhadap waktu keluar bunga, dimana waktu keluar bunga pada pada jagung hibrida tercepat pada perlakuan P2 jarak tanam $100 \mathrm{~cm} \times 50 \mathrm{~cm} \times 20 \mathrm{~cm}$ sebesar 48.9 hst dan terlama pada perlakuan P9 jarak tanam $75 \mathrm{~cm} \times 15 \mathrm{~cm}$ yaitu sebesar 50.6 hst. Hal ini menunjukkan semakin rapat jarak tanam mengakibatkan umur berbunga tanaman jagung semakin lambat, sebaliknya semakin jarang jarak tanam semakin cepat waktu keluar bunga jantan/betina

\section{Kandungan Klorofil}

Hasil analisis keragaman menunjukkan bahwa perlakuan jarak tanam berpengaruh tidak nyata terhadap kandungan klorofil pada tanaman jagung non hibrida (Tabel 4). Perlakuan jarak tanam P3 $(75 \mathrm{~cm}$ x $20 \mathrm{~cm})$ memberikan nilai tertinggi sebesar 52,6 kandungan 
klorofil tanaman jagung pada umur 50 hst, sedangkan terendah pada perlakuan (P9) sebesar 44,6.

Berat berangkasan kering jagung hibrida tertinggi pada perlakuan $\mathrm{P} 2$ sebesar (227.6 g tanaman ${ }^{-1}$ ), dan terendah yaitu pada perlakuan P8 sebesar $(78.20 \mathrm{~g}$ $\left.\operatorname{tanaman}^{-1}\right)$, sedangkan nilai berat berangkasan kering jagung non hibrida pada perlakuan P1 sebesar (163.6 g tanaman $\left.^{-1}\right)$, dan terendah yaitu pada perlakuan P9 sebesar (87.0 $\left.\mathrm{g} \mathrm{tanaman}^{-1}\right)$.

\section{Berat Berangkasan Kering}

Hasil analisis keragaman menunjukkan bahwa perlakuan jarak tanam berpengaruh sangat nyata terhadap berat berangkasan kering. Nilai berat berangkasan kering jagung tertinggi pada perlakuan P1 $(80 \mathrm{~cm}$ x $20 \mathrm{~cm})$ sebesar 163,5 $\mathrm{g} \tan ^{-1}$, sedangkan nilai terendah pada perlakuan P9 yaitu 87,0 $\mathrm{g} \mathrm{tan}^{-1}$.

Hasil penelitian menunjukkan jarak tanam yang semakin rapat akan berpengaruh terhadap penurunan berat berangkasan, semakin tinggi populasi dan semakin rapat jarak tanam berat berangkasan kering per tanaman semakin rendah, sedangkan pada populasi tanaman yang renggang dan jarak tanam yang tidak begitu rapat memberikan peluang terhadap penyerapan unsur hara, air dan cahaya. Berat kering berangkasan menggambarkan hasil bersih dari fotosintesis (Nurjen et al. 2002).

\section{Hasil dan Komponen Hasil Tanaman Jagung}

Tabel. 5. Pengaruh perlakuan jarak tanam terhadap hasil dan komponen hasil diamati setelah penelitian.

\begin{tabular}{ccccccccc}
\hline $\begin{array}{c}\text { Perlakua } \\
\mathrm{n}\end{array}$ & $\begin{array}{l}\text { Panjan } \\
\mathrm{g} \\
\text { tongko }\end{array}$ & $\begin{array}{c}\text { Diamet } \\
\text { er }\end{array}$ & $\begin{array}{c}\text { Jumlah } \\
\text { baris/tongkol biji/tong } \\
\text { kol }\end{array}$ & $\begin{array}{c}\text { Jumlah } \\
\text { kering } \\
\text { klobot }\end{array}$ & $\begin{array}{c}\text { Berat } \\
\text { kering } \\
\text { janggel }\end{array}$ & $\begin{array}{c}\text { Berat } \\
1000 \\
\text { butir biji }\end{array}$ & $\begin{array}{c}\text { Produksi } \\
\text { pipilan } \\
\text { kering }\end{array}$ \\
\hline P1 & $19,8 \mathrm{a}$ & $4,9 \mathrm{ab}$ & $36,6 \mathrm{a}$ & $513,3 \mathrm{a}$ & $21,8 \mathrm{a}$ & $25,100 \mathrm{a}$ & $281 \mathrm{a}$ & $4,2 \mathrm{ab}$ \\
P2 & $19,5 \mathrm{a}$ & 4,8 & $34,2 \mathrm{a}$ & & $21,3 \mathrm{a}$ & $27,133 \mathrm{a}$ & $303 \mathrm{a}$ & $4,0 \mathrm{ab}$ \\
P3 & $20,0 \mathrm{a}$ & $\mathrm{ab}$ & $31,3 \mathrm{a}$ & $475,3 \mathrm{ab}$ & $21,8 \mathrm{a}$ & $24,700 \mathrm{a}$ & $288 \mathrm{ab}$ & $3,6 \mathrm{~b}$ \\
P4 & $18,5 \mathrm{ab}$ & $5,1 \mathrm{a}$ & $31,6 \mathrm{ab}$ & & $21,0 \mathrm{a}$ & $23,366 \mathrm{a}$ & $283 \mathrm{ab}$ & $3,4 \mathrm{~b}$ \\
P5 & $18,2 \mathrm{~b}$ & 4,4 & $28,4 \mathrm{c}$ & $410,7 \mathrm{bc}$ & $17,6 \mathrm{a}$ & 27,000 & $283 \mathrm{ab}$ & $3,5 \mathrm{~b}$ \\
P6 & $17,3 \mathrm{~b}$ & $\mathrm{ab}$ & $27,1 \mathrm{c}$ & $410,7 \mathrm{bc}$ & $17,9 \mathrm{a}$ & $\mathrm{ab}$ & $271 \mathrm{bc}$ & $3,1 \mathrm{~b}$ \\
P7 & $18,3 \mathrm{ab}$ & $4,7 \mathrm{c}$ & $26,6 \mathrm{bc}$ & $382,7 \mathrm{~cd}$ & $21,2 \mathrm{a}$ & 23,066 & $285 \mathrm{~b}$ & $4,2 \mathrm{ab}$ \\
P8 & $13,2 \mathrm{c}$ & $4,4 \mathrm{c}$ & $22,5 \mathrm{~d}$ & & $12,3 \mathrm{~b}$ & $\mathrm{ab}$ & $247 \mathrm{~cd}$ & $4,1 \mathrm{ab}$ \\
P9 & $11,7 \mathrm{c}$ & $4,6 \mathrm{c}$ & $21,8 \mathrm{~d}$ & $345,7 \mathrm{de}$ & $13,2 \mathrm{~b}$ & $24,933 \mathrm{a}$ & $245 \mathrm{~cd}$ & $4,9 \mathrm{a}$ \\
& & $3,6 \mathrm{~d}$ & & $368,3 \mathrm{e}$ & & $18,300 \mathrm{bc}$ & & \\
& & $3,6 \mathrm{~d}$ & & $262,0 \mathrm{e}$ & & $15,533 \mathrm{c}$ & & \\
& & & & $250,3 \mathrm{f}$ & & & &
\end{tabular}

\section{Panjang Tongkol}

Hasil analisis keragaman panjang tongkol menunjukkan bahwa jarak tanam berpengaruh sangat nyata. Berdasarkan tabel 5 perlakuan P1 sampai P7 tidak berbeda nyata, tetapi berbeda nyata dengan perlakuan P8 dan P9. Perlakuan P3 panjang tongkol tertinggi dengan rata-rata sebesar 20,0 cm, sedangkan nilai terendah pada perlakuan $\mathrm{P} 9$ sebesar $11,7 \mathrm{~cm}$.

\section{Diameter Tongkol}

Berdasarkan hasil analisis keragaman menunjukkan bahwa perlakuan jarak tanam berpengaruh sangat 
nyata terhadap diameter tongkol tanaman jagung non hibrida Srikandi.

Uji Beda Nyata (BNT) pengaruh perlakuan jarak tanam terhadap diameter tongkol disajikan pada tabel 5 perlakuan P1 sampai P7 tidak berbeda nyata, tetapi berbeda nyata dengan perlakuan P8 dan P9. Perlakuan P3 diameter tongkol tertinggi dengan rata-rata sebesar $5,1 \mathrm{~cm}$, sedangkan nilai terendah pada perlakuan P8 dan P9 yaitu sebesar 3,6 cm.

\section{Jumlah Baris Per Tongkol}

Berdasarkan hasil analisis keragaman menunjukkan perlakuan jarak tanam berpengaruh sangat nyata terhadap jumlah baris per tongkol. Berdasarkan tabel 5 perlakuan P1, P2, P3, P4,P5, P6, dan P7 menunjukkan perlakuan berpengaruh tidak nyata terhadap jumlah baris per tongkol, tetapi berbeda nyata pada perlakuan P8 dan P9. Pada perlakuan P1 mempunyai jumlah baris per tongkol tertinggi yaitu rata-rata $36,1\left(\tan ^{-1}\right)$ dan jumlah baris per tongkol terendah terdapat pada perlakuan P9 sebesar 21,8 $\left(\tan ^{-1}\right)$.

\section{Jumlah Biji Per Tongkol}

Berdasarkan hasil analisis keragaman menunjukkan perlakuan jarak tanam berpengaruh sangat nyata terhadap jumlah biji per tongkol.

Uji Beda Nyata (BNT) pengaruh perlakuan jumlah populasi dan jarak tanam terhadap jumlah biji per tongkol. Berdasarkan tabel 5 perlakuan P1, P2, P3, P4,P5, P6, dan P7 menunjukkan perlakuan berpengaruh tidak nyata terhadap jumlah biji per tongkol, tetapi berbeda nyata pada perlakuan P8 dan P9. Pada perlakuan P1 mempunyai jumlah biji per tongkol tertinggi yaitu rata-rata 513,3 $\left(\tan ^{-1}\right)$ dan jumlah baris per tongkol terendah terdapat pada perlakuan P9 sebesar 250,3 $\left(\tan ^{-1}\right)$.

\section{Berat Kering Klobot}

Berdasarkan hasil analisis keragaman menunjukkan perlakuan jarak tanam berpengaruh sangat nyata terhadap berat kering klobot.

Uji Beda Nyata (BNT) pengaruh perlakuan jumlah populasi dan jarak tanam terhadap berat kering klobot. Berdasarkan tabel 5 perlakuan P1 sampai P7 menunjukkan perlakuan berpengaruh tidak nyata terhadap berat kering klobot, tetapi berbeda nyata pada perlakuan P8 dan P9. Pada perlakuan P1 dan P3 berat kering klobot tertinggi yaitu rata-rata 21,8 gr sedangkan nilai terendah8 terendah terdapat pada perlakuan P9 sebesar 12,3 gr.

\section{Berat Kering Janggel}

Berdasarkan hasil analisis keragaman menunjukkan perlakuan jarak tanam berpengaruh sangat nyata terhadap berat kering janggel.

Uji Beda Nyata (BNT) pengaruh perlakuan jumlah populasi dan jarak tanam terhadap berat kering janggel. Berdasarkan tabel 5 perlakuan P1 sampai P7 menunjukkan perlakuan berpengaruh tidak nyata terhadap berat kering janggel, tetapi berbeda nyata pada perlakuan P8 dan P9. Pada perlakuan P2 dengan nilai tertinggi yaitu rata-rata $27,133 \mathrm{gr}$ dan terendah terdapat pada perlakuan P9 sebesar 15,533 gr.

\section{Berat 1000 Butir}

Berdasarkan hasil keragaman berat 1000 butir biji jagung perlakuan jarak tanam menunjukkan bahwa perlakuan berpengaruh sangat nyata

Uji Beda Nyata (BNT) pengaruh perlakuan jumlah populasi dan jarak tanam terhadap berat kering janggel. Berdasarkan tabel 5 perlakuan P1 sampai P7 menunjukkan perlakuan berpengaruh tidak nyata terhadap berat kering janggel, tetapi berbeda nyata pada perlakuan P8 dan P9. Pada perlakuan P2 jumlah berat 1000 biji nilai tertinggi yaitu rata-rata 303 gr dan terendah terdapat pada perlakuan P9 jumlah berat 1000 biji sebesar 245 gr. 


\section{Produksi Jagung Pipilin Kering}

Berdasarkan hasil keragaman produksi jagung pipilin kering perlakuan jarak tanam menunjukkan bahwa perlakuan berpengaruh sangat nyata

Uji Beda Nyata (BNT) pengaruh perlakuan jumlah populasi dan jarak tanam terhadap produksi jagung pipilin kering. Berdasarkan tabel 5 perlakuan P1 sampai P8 menunjukkan perlakuan berpengaruh tidak nyata terhadap produksi jagung pipilin kering, tetapi berbeda nyata pada perlakuan P9. Pada perlakuan P9 jumlah berat produksi jagung pipilin kering nilai tertinggi yaitu rata-rata 4,9 ton/ha dan terendah terdapat pada perlakuan P6 produksi jagung sebesar 3,1 ton/ha pipilin kering

Dari hasil penelitian perlakuan jarak tanam P1 dan P2 merupakan pengaturan jarak tanam yang baik terhadap penanaman jagung, mendapatkan pertumbuhan dan produksi jagung yang baik. Hal ini diduga pada jarak tanam yang tepat mengakibatkan tidak terjadi persaingan untuk mendapatkan unsur hara, faktor yang mendapatkan sinar matahari, tidak terjadi saling ternaungi antara tanaman yang dibutuhkan oleh tanaman.

Pengaturan jarak tanam P1 $(80 \mathrm{~cm}$ x $20 \mathrm{~cm})$, dan P2 (100 cm x $50 \mathrm{~cm}$ x 20 $\mathrm{cm}$ ) berpengaruh sangat nyata terhadap pertumbuhan jagung pada tinggi tanaman, indeks luas daun. Hal ini diduga (Erawati.dkk.2016: 609), Populasi tanaman (jarak tanam) merupakan salah satu faktor yang dapat mempengaruhi hasil tanaman. Peningkatan hasil jagung dapat diupayakan melalui pengaturan kerapatan tanam hingga mencapai populasi optimal. Menurut Gardner et al. (1996), pengaturan kerapatan tanaman bertujuan untuk meminimalkan kompetisi intrapopulasi agar kanopi dan akar tanaman dapat memanfaatkan lingkungan secara optimal. Jumlah tanaman yang berlebihan akan menurunkan hasil karena terjadi kompetisi terhadap unsur hara, air, radiasi matahari, dan ruang tumbuh sehingga akan mengurangi jumlah biji pertanaman (Irfan 1999). Yulisma (2011), jarak tanam yang terlalu rapat akan menghambat pertumbuhan tanaman, tetapi jika terlalu jarang akan mengurangi populasi per satuan luas.

Pada penelitian ini, jumlah populasi yang optimum akan dipengaruhi pada semua peubah yang diamati, dimana pada perlakuan jumlah populasi yang rendah, semua peubah menunjukkan hasil terbaik. Misalnya peubah pertumbuhan tanaman hasil serta komponen hasil. Menurut Soeprapto.1993 dalam Trimin. 2014:46, bahwa jarak tanam yang tepat adalah penting dalam pemanfaatan cahaya matahari secara optimum untuk proses fotosintesis. Fotosintesis adalah proses dimana karbondioksida dan air dibawah pengaruh cahaya matahari diubah kedalam persenyawaan organik yang berisi karbon dan kaya energi. Laju fotosintesis berhubungan dengan ketersediaan bahan mentah, yaitu air dan karbondioksida dan energi yang tersedia dalam benrtuk panas.

Populasi yang semakin rapat dan yang semakin renggang (melebihi batas optimum) cenderung menurunkan hasil tanaman. Terjadinya penurunan hasil pada jarak tanam yang rapat disebabkan karena daun-daun pada populasi tersebut saling menaungi, sehingga hanya daun-daun bagian atas saja yang menerima cahaya matahari. Hal ini mengakibatkan aktivitas fotosintesis pada populasi yang optimum, sehingga berpengaruh terhadap prosesproses metabolisme tanaman dan akibatnya translokasi hasil-hasil fotosintesis ke biji berkurang.

Pada jumlah populasi yang rendah dan jarak tanam yang semakin renggang (melebihi batas optimum), area permukaan tanah yang tidak ternaungi tanaman lebih lebar sehingga evaporasi tanah lebih tinggi dan unsur yang terkandung di dalam tanah lebih banyak 
menguap daripada diserap oleh tanaman.

Akibatnya tanaman mengalami kekurangan unsur hara sehingga pertumbuhannya menjadi terganggu. (Trimin.2014: 47).

Pengaturan jarak tanam mempengaruhi lingkungan fisik secara tidak langsung maupun secara langsung melalui kompetisi antara tanaman dalam memanfaatkan air, unsur hara dan cahaya. Unsur-unsur lingkungan fisik, satu sama lain saling berkaitan. Cahaya dapat dianggap sebagai unsur lingkungan fisik yang utama, tinggi rendahnya suhu terjadi karena adanya perubahan intensitas cahaya matahari sebagai sumber utama energi panas. Kelembaban udara tergantung kepada keadaan suhu selain presipitasi Edhie et al, (1979). Secara umum dapat dikatakan bahwa varietas jagung hibrida Bisi-9 cenderung memiliki potensi genetik yang lebih baik. Hal ini tercermin dari hasil analisis keragaman yang diperoleh dalam penelitian ini (Tabel $1)$.

Menurut Sutoro et al. (1988), peningkatan produksi jagung dapat dilakukan dengan cara perbaikan tingkat kerapatan tanaman (jarak tanam). Peningkatan tingkat kerapatan tanaman per satuan luas sampai suatu batastertentu dapat meningkatkan hasil biji. Sebaliknya pengurangan kerapatan tanaman jagung perhektar dapat mengakibatkan perubahan iklim mikro yang mempengaruhi pertumbuhan dan hasil jagung.

Dari semua peubah pertumbuhan tanaman hasil dan komponen hasil sangat berpengaruh terhadap jumlah populasi dan jarak tanaman tanaman jagung memperlihatkan bahwa produksi pipilan kering dari pertumbuhan perlakuan P1 dan P2 memberikan nilai yang optimum, tetapi dilihat dari hasil produksi pipilan kering jagung non hibrida berpengaruh nyata terhadap peningkatan hasil pipilan kering jagung pada perlakuan P9 jarak tanam 75 $\mathrm{cm} \times 15 \mathrm{~cm}$ sebesar 4,9 ton/ha.

\section{KESIMPULAN}

Berdasarkan hasil dari penelitian ini yang telah dilakukan dapat disimpulkan bahwa:

1. Pemakaian jarak tanam yang jarang dapat meningkatkan pertumbuhan dan produksi tanaman jagung.

2. Pada jarak tanam $80 \mathrm{~cm} \times 20 \mathrm{~cm}$, dan jarak tanam $100 \mathrm{~cm} \times 50 \mathrm{~cm} \times 20 \mathrm{~cm}$, memberikan pengaruh terbaik terhadap pertumbuhan dan produksi tanaman jagung.

3. Jagung non hibrida Srikandi dengan pemakaian jarak tanam $75 \mathrm{~cm}$ x 15 $\mathrm{cm}$ memberikan hasil tertinggi sebesar 4,9 ton/ha .

\section{DAFTAR PUSTAKA}

Badan Pusat Statistik. (2012). Produktivitas Jagung dan Kedelai. (Angka Tetap 2011 dan Angka Ramalan 1 2012).BPS No. 43/07/Th.XV.2 Juli 2012.Jakarta.

Djauhari, A;M, Syani; A. Malian dan M.G. Van Der Veen. (1987). Latihan Metode Penelitian Teknik Budidaya Tanaman Pangan dan Industri Badan Penelitian dan Pengembangan Pertanian Nusa Tenggara.

Edhie, S.J.S. Bahasjah, M.H. Bintaro dan Sutarwi, S. (1979). Pengaruh Pengaturan Jarak Tanam Terhadap Lingkungan Fisik Pertumbuhan dan Produksi Tanaman Jagung (Zea mays L). Buletin Agronomi x (1).

Erawati.T., Hipi.A. (2016). Pengaruh Jarak Tanam terhadap Pertumbuhan dan Hasil Beberapa Varietas Jagung Hibrida di Kawasan Pengembangan Jagung Kabupaten Sumbawa. Prosiding 
Seminar Nasional Inovasi Teknologi Pertanian Banjarbaru.

Gardner, F. P. Pearce. R. B. and Michell. R. L. (1996). Physiology of crop plant. Terjemahan Herawati, Susilo, dan Subiyanto. UI Pres, Jakarta. p. $61-68 ; 343$.

Gerry Dian, S, (2004), Pengaruh Kombinasi Dosis Pupuk Nitrogen dan Pupuk Kandang Sapi Pertumbuhan dan Hasil Tanaman Jagung Manis pada Jarak Tanam yang Berbeda, Universitas Brawijaya, Malang.

Haryadi.S.S. (1988). Pengantar Agronomi. Gramedia. Jakarta.

Irfan, M. (1999). Respon Tanaman Jagung (Zea mays L.) terhadap Pengolahan Tanah dan Kerapatan Tanam pada Tanah Andisol. Tesis Program Pasca Sarjanah USU, Medan. P. 13-74.

Kartika,T. (2014). Respon Pertumbhan dan Produksi Jagung (Zea mays L) Hibrida pada Tingkat Populasi yang Berbeda. Jurnal SAINMATIKA. Vol. 11 No. 2. 2014. 74.

Riset dan Kerjasama Teknologi. (2003). Budidaya Tanaman Jagung. Kerjasama Kementrian Riset dan Teknologi dengan Fakultas Pertanian Universitas Sriwijaya.

Maruapey A. (2011). Pengaruh jarak tanam dan jenis pupuk kanang terhadap pertumbuhan gulma dan hasil jagung manis. Seminar Nasional Serelia 2011.

Mejaya, M. J., Dahlan, M., \& Pabendon, M. (2005). Pola heterosis dalam pembentukan varietas unggul jagung bersari bebas dan hibrida. In Seminar Bulanan Pusat Penelitian dan Pengembangan Tanaman Pangan, Bogor (Vol. 12).

Nurjen,M. Sudiarso, A. Nogroho. (2002). Peranan Pupuk Kotoran Ayam dan Nitrogen (UREA) terhadap Pertumbuhan dan Hasil Kacang (Phaseolus radiatus L) Varietas Sriti. Journal Agrivita, Vol. 24. No. 1. hhtp://www.digilip. Brawijaya, ac. Id/.virtual.

Probowati, R.A., B. Guritno, dan T. Sumarni. (2014). Pengaruh tanaman penutup tanah dan jarak tanam pada gulma dan hasil tanaman jagung (Zea mays L.).

Jurnal Produksi Tanaman Vol 2 , No 8 (2014). Publisher: Jurusan Produksi Tanaman Fakultas Pertanian Universitas Brawijaya.

Subandi, Zubachtirodin, S. Saenong, dan I.U. Firmansyah. (2006). Ketersediaan teknologi produksi dan program penelitian jagung. Dalam: Prosiding Seminar dan Lokakarya Nasional Jagung 29-30 September 2005 di Makassar. Pusat Penelitian dan Pengembangan Tanaman Pangan.Bogor. p. 11-40

Sutoro, Soelaeman, Y. \& Iskandar. (1988). Budidaya Tanaman Jagung. Balai Penelitian Tanaman Pangan, Bogor

Soeprapto. (1993). Bertanam Kacang Hijau. Penebar Swadaya. Jakarta.

Yulisma. (2011). Pertumbuhan dan Hasil Beberapa Varietas Jagung pada Berbagai Jarak Tanam.Penelitian Pertanian Tanaman Pangan. Vol.3 No.2. 201 